of a potential cell. Such models can in all cases lead to a finite expansion viscosity. A relaxation time can be involved in the readjustment of the molecules in potential cells to a small change in external conditions. He thought that any explanation of the behaviour of water must explain the variation of both the viscosity and the absorption with temperature, since these are so closely related. The distinctions drawn between associated and non-associated liquids make it clear that different theories must be developed for the two cases.

In the discussion contributions were made by Dr. P. Vigoureux, Mr. Bayard, Mr. D. O. Sproule, Dr. J. Lamb, Mr. Ribchester and Mr. E. Bauer. Dr. Lamb referred to the theoretical papers by Dutta ${ }^{14}$, and Dutta and Ghosh ${ }^{15}$ on dispersion and absorption of ultrasonic waves in liquids, and measurements by Rapuano ${ }^{16}$ up to $250 \mathrm{Mc}$./s. Venkatswaran ${ }^{17}$ had not confirmed Raman and Rao's results for dispersion of hypersonic waves.

${ }^{1}$ Stokes, G. G., Trans. Camb. Phil. Soc., 8, 287 (1845).

2 Kirchhoff, G., Pogg. Ann., 134, 177 (1868).

${ }^{3}$ Biquard, P., Ann. de Physique, 6, 195 (1936).

"Pellam, J. R., and Galt, J. K., J. Chem. Phys., 14, 608 (1946).

${ }^{5}$ Pinkerton, J. M. M., Nature, 160, 128 (1947).

"Willard, G. W., J. Acous. Soc., 12, 438 (1941).

"Hunter, J. L., J. Acous. Soc., 13, 36 (1941).

${ }^{8}$ Ringo, G. R., Fitzgerald, J. W., and Hurdle, B. G., Phy8. Rev., 72, 87 (1947).

${ }^{9}$ Kneser, H. O., Ann. d. Phys., 32, 277 (1938).

${ }^{10}$ Mandelstam, 1., and Leontovitsch, M., J. Exp. Theor. Phys., 7, 438 (1937).

${ }^{11}$ Raman, C. V., and Rao, B. V. R., Nature, 135, 161 (1935).

12 Tisza, L., Phys. Rev., 61, 531 (1942).

${ }^{13}$ Hall, L., Phys. Rev., '11, 318 (1947).

14 Dutta, A. K., Trans. Bose Research Inst., 12, 115 (1936-87).

15 Dutta, A. K., and Ghosh, Trans. Bose Research Inst., 13, 30 (1937-38).

10 Rapuano, R. A., Phys. Rev., "72, 78 (1947).

17 Venkatswaran, C. S., Proc. Ind. Acad. Sci., 15, 371 (1942).

\section{FUTURE OF AGRICULTURE IN BRITAIN}

$I^{\mathrm{N}}$

a Friday evening discourse at the Royal Institution on October 31, Lord De La Warr discussed the prospects of British agriculture and how far it could help to moet the country's present problems of a shortage of dollars and the threat of an actual scarcity of food. The first essential, he said, is to decide the true nature of the trouble, whether it is a 'crisis' of temporary duration only or whether we are not rather being confronted with a fundamental change in our national economy. If the difficulties are merely short-term, it would seem that British agriculture has little contribution to make, since production has declined over the last two years both as regards acreage of tillage and livestock figures, and time will be needed to reverse this trend. Though increase of livestock may be the best way of farming to save dollars, the opportunity, which offered itself twelve months ago, of buying adequate feeding stuffs to do this had not been taken, so that the prospect of building up an animal population rapidly is not hopeful. During the last two years the whole world food situation has gone from bad to worse, and though this may be no one's fault, it must be admitted that interest in agricultural matters has been sadly lacking in the British nation as a whole. The word 'crisis' is, in fact, quite misleading, and its use has prevented us from realizing that the start we gained in the industrial revolution has run out and that cheap food and raw materials, with the consequent high standard of living to which we had become accustomed, can no longer be taken for granted. The idea that when the present 'crisis' ends we shall again be able to import all the food we require at a low price must be abandoned before we can hope to rebuild our shattered economy.

During the last five years before the War, Great Britain was importing on an average $£ 50$ million per annum more than it was exporting; that is, we had already begun to live beyond our means, and since then we have raised our standard of living. Countries such as Canada, Australia and South America, that in the past were mainly food producers, have been steadily industrializing themselves, thereby decreasing their demands for British exports. Great Britain is, in consequence, not likely to be in a financial or economic position to pay for importing as large a proportion of food as formerly, and may even have difficulty in exporting sufficient to pay for essential raw material to maintain her factories. It is questionable, moreover, whether the food is even available, assuming we had the money to pay for it. Besides the changes brought about by the industrialization of the great food-producing countries, there are those due to alterations in farming methods. The switchover from cereal growing to livestock production that has occurred in the 'dust bowl' areas of the United States and Canada means less grain available for human requirements. Furthermore, enormous increases in population are taking place in India and Africa, as well as a rise in the consumption per head in these countries, due to the efforts to improve the standards of health and nutrition among the native peoples.

Other factors may prove of importance in determ. ining future trends. The control of the tsetse fly and locust, for example, would open up new regions for agricultural development, which in their turn might temporarily offset this increased demand for food. On the other hand, the elimination of the mosquito would result in an even more rapid rise in population in many areas.

For the purpose of feeding the people of Great Britain, the products of British agriculture are, therefore, literally of vital importance. The increase of $£ 100$ millions of food by 1952 demanded by the Government is moderate from the point of view of the potentialities of the soil and the needs of the situation. In terms of the facilities now available, of labour, houses, machinery, fertilizers and feeding stuffs, however, the target is not likely to be reached unless the drive behind it is intensified. It is the country, not the farming industry, that will suffer if the necessary increased production is not attained, and the facts and figures available point to the strong possibility of real hunger being experienced during the next twelve months. However, the soil of Britain is capable of producing more. Four years ago, $1 \frac{1}{2}$ million acres more were under cultivation than to-day, and there were more pigs and sheep and about the same number of cattle.

More knowledge and better application of existing knowledge are needed. Means must be found for carrying over new information particularly to the small farmer, and an improvement in the national standard of education is probably the best solution to this problem. Compared with other countries, the farming efficiency in Britain is high; more is produced per head than in any other country in Europe, 
and we grow $2 \frac{1}{2}$ times as much wheat per acre as in the United States or Canada. We are highly mechanized and in many cases our costs compare well with what we have to import. Both soil and climate are in our favour and our workers are good. The root of our trouble is the national unwillingness to realize that this is no 'crisis' with which we are faced, but a long-term, if not permanent, change. Not until this is completely accepted will the requisite national energy be put behind our agricultural drive. Labour, houses, machinery, fertilizers and feeding stuffs are our immediate needs. But they are only the beginning. Whatever our shortages and difficulties may be, the countryside must be re-equipped with new buildings, houses, electricity, water and transport. We need the best that science can give, and we are gradually drawing into agricultural research some of the best brains that science can produce. But we need more; in fact, if the land of Great Britain is to yield of its best, it will demand a greater share of every section of our national wealth, its energies, capital, income, raw material and, above all, its brains.

Even so, it will take time to achieve the necessary increased production, and when we have achieved it, we shall not have solved the whole problem of feeding the 45 million people who inhabit Great Britain. Neither agriculture nor any other single industry can provide a panacea. In fact, one of the greater lessons that this generation will have to learn from the coming hard times is to give up this passionate belief that panaceas exist. But granted the readiness of the nation to change, and change fundamentally, its whole attitude to agriculture, there is no other industry in the country that can make as great a contribution-long-term contribution - to the future of Great Britain.

\section{PATHOLOGY OF GLASSHOUSE CROPS}

$\mathrm{T}$ HE thirty-first annual report for 1945 of the Cheshunt Experimental and Research Station ('Turner's Hill, Cheshunt, Herts, 1946) sets forth the results of several pieces of research into the pathology of glasshouse crops.

P. H. Williams has investigated the effect of temperature and humidity on the pathogenicity of Verticillium albo-atrum and $V$. dahlioe. He finds that $V$. albo-atrum made very little progress when inoculated to tomato plants growing in a closed chamber, with temperature and humidity higher than normal. The plants did not wilt in this environment. $V$. dahlice, on the other hand, caused about the same amount of disease in a closed chamber and under normal conditions. Verticillium wilts do not appear to owe greater severity of attack to increasing soil moisture. Cucumber plants wilted under conditions which checked the disease due to $V$. alboatrum in tomatoes.

The fungus Didymella lycopersici causes a severe stem rot of tomato plants. Mrs. Enid Sheard has shown that the disease can spread by air-borne spores, that an attack is more severe where plants are grown in soil which has been steam-sterilized before inoculation than in unsterilized soil, and that the fungal strain which attacks only the fruit of outdoor tomatoes will not cause stem rot under glass. With O. B. Orchard, Mrs. Sheard has found that aerial infection is controlled by fumigation with formaldehyde vapour. W. H. Read has also attempted control of the disease by applying various fungicides to the surface soil of glasshouses, before and during planting.

I. W. Selman has found that fruiting tomato plants may show marked resistance to invasion by mosaic virus, and that inorganic nutrition also has an effect in promoting resistance to mosaic. Experiments are in hand to determine the nutrient balance most favourable to resistance. An interesting application for disease control by antibiotics is investigated by Erma Grossbard. A strain of Aspergillus clavatus has been used to depress the incidence of 'damping off' of tomato seedlings by the fungus Phytophthora cryptogea. Antibiotic properties were also demon. strated against Bacillus carotovorus. Further trials with petroleum emulsion for the control of red spider mite have been made by E. R. Speyer and W. J. Parr. Large-scale use of D.D.T. has proved of value against the tomato moth, but applications of sodium ethyl xanthate against root-knot eelworm have not provided much hope of commercial control.

Several non-pathological investigations have also been made. They include the Station's continued work on general cultivation, an evaluation of the use of sulphur and sulphuric acid for making alkaline soils more acid, the choice of extractants in soil analysis, and the effect of plant hormones on the setting of tomato fruit.

\section{FORTHCOMING EVENTS}

\author{
Wednesday, December 31
}

ROYAL MicRoscopical SOCIETY, SHCTION OF INDCSTRIAL MIOROSCOPY (in the Hastings Hall, B.M.A. House, Tavistock Square, London, W.C.1), at 5.30 p.m.-Mr. F. D. Armitage : "Microscopy of Paper".

\section{APPOINTMENTS VACANT}

APPIICATIONs are invited for the following appointments on or before the dates mentioned

ENGINEER IN THE AUDIO FREQURNCY SECTION of the Research Department, based in London, ENGINERRS (2) IN THE FIELD STRENGTH Stiction of the Research Department, based at Oxford, ENGINGERS (senior and junior) IN THE DESIGNS DEPARTMENT in London-The Engineering Establishment Officer, B.B.C., Broadcasting House, London, W.1 (January 3)

Assistant Chemists (2) in The Chemistry BRANCH of the Department of Agriculture and Lands, Southern Rhodesia-The Office of the High Commissioner for Southern Rhodesia, 429 Strand, London, W.C.2 (January 5).

SUPERINTENDENT IN THE SHIP DIVISION of the National Physical Laboratory in the Department of Scientifle and Industrial ResearchThe Secretary, Civil Service Commission, Scientific Branch, 27 Grosvenor Square, London, W.1, quoting No. 2065 (January 7).

RANKIN LECTURER (Grade I) IN THF PRRHISTORTO ARCHMOLOGY of W RATRN ETROPE, and a CHARIES W. JONFs LROTURER (Grade II) IN

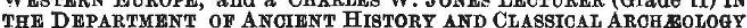

-The Registrar, The University, Liverpool (January 8). Secretary Universities Bureau of the British Empire, 8 Park Street. London, W.1 (January 12).

PRINCIPAL SCIRNTIFIO OFFICER at the Royal Air Force Institute of Aviation Medicine, Farnborough, Hants, under the Air MinistryThe Secretary, Civil Service Commission, Scientific Branch, 27 Grosvenor Square, London, W.1, quoting No. 2071 (January 12). Grosvenor Square, London, W.1, quoting No. 2071 (January 12)
CHIEF CoNsERvitroN OFFTER in charge of the Conservation
Branch of the Irrigation Department, Southern Rhodesia-Office of the High Commissioner for Southern Rhodesia, 429 Strand, London, W.C.2 (January 21).

W. D.2 (January 21 . DIRECTOR OF MUSEUMS-The Town Clerk, Municipal Buildings,
Dale Street, Liverpool 2, endorsed 'Director of Museums' (January 26). CHFMsT for an investigation of the isolation and analysis of the CHEMIST for an investigation of the isolation and analysis of the
insecticidal constituents of pyrethrum flowers-Dr. S. H. Harper. insecticidal constituents of pyrethrum flowers-Dr. S. H. Harper. Chemistry Dep

(January 31). HRAD OF THE DEPARTMENT OF PHYSIOS (Senior Lecturer)-The
Secretary, St. Mary's Hospital Medical School, Paddington, London,

W.2 (January 31). Director, National Museum of Wales, Cardiff DIRECTOR-

(February 28). LHFTURER IN THE DEPARTMENT OF ELECTRICAL ENGINEERING AND
PHYSIOS-The Principal, Borough Polytechnic, Borough Road, London, S.E.1. 